\title{
Original Paper / Artigo Original \\ Host tree bark traits and development of reintroduced Cattleya intermedia (Orchidaceae) plants in Southern Brazil
}

\author{
Delio Endres Júnior ${ }^{1,3}$, Márcio Hisayuki Sasamori ${ }^{1}$, Camila Tamires Petry ${ }^{2}$, Miguel da Silva Santos ${ }^{2}$ \\ \& Annette Droste
}

\begin{abstract}
The traits of the bark of host trees can influence the distribution and development of epiphytes. Bark samples were suspended in 10 and $20 \mathrm{~mL}$ of distilled water for 1, 4 and $24 \mathrm{~h}$, to evaluate $\mathrm{pH}$ determination methods. Bark samples of Myrcia brasiliensis, M. glabra and Myrsine coriacea, three host trees of Cattleya intermedia had bark samples collected from the trunk and the crown, for the evaluation of the $\mathrm{pH}$, water retention capacity and thickness. Shoot height $(\mathrm{cm})$ and number of roots of $C$. intermedia grown on trunk and into the crown of the three species were evaluated. Volume of solvent and suspension time of the bark samples influenced $\mathrm{pH}$ values. The $\mathrm{pH}$ and thickness of Myrsine coriacea barks were higher when compared to Myrcia species. Shoot height and number of roots of $C$. intermedia individuals were significantly higher in the crown. The growth parameters of the reintroduced plants were unrelated to $\mathrm{pH}$ and bark thickness. The data bring information for the application of further vascular epiphyte studies including new parameters and greater samplings, in order to support proposals of the conservation of endangered species.
\end{abstract}

Key words: bark features, conservation, plant ecophysiology, vascular epiphytes.

\section{Resumo}

As características das cascas de árvores hospedeiras podem influenciar na distribuição e no desenvolvimento de epífitos. Amostras de casca foram suspensas em 10 e $20 \mathrm{~mL}$ de água destilada por 1, 4 e $24 \mathrm{~h}$, para avaliação de métodos para a determinação do pH. Cascas de Myrcia brasiliensis, M. glabra e Myrsine coriacea hospedeiras de Cattleya intermedia foram coletadas no fuste e na copa, para avaliação do $\mathrm{pH}$, da capacidade de retenção de água e da espessura. A altura da parte aérea e o número de raízes de $C$. intermedia crescidas no fuste e na copa das três espécies de árvore foram avaliados. O volume de solvente e o tempo de suspensão da casca influenciaram nos valores de $\mathrm{pH}$. O pH e a espessura da casca de Myrsine coriacea foram maiores do que nas espécies de Myrcia. A altura da parte aérea e o número de raízes dos indivíduos de $C$. intermedia foram superiores na copa. Os parâmetros de crescimento das plantas não se relacionaram com o pH e a espessura da casca. Os dados trazem informações para subsequentes estudos sobre epífitos vasculares que incluam novos parâmetros e maiores amostragens, visando a subsidiar propostas de conservação de espécies ameaçadas.

Palavras-chave: atributos da casca, conservação, ecoficiologia vegetal, epífitos vasculares.

\section{Introduction}

The distribution of epiphytic plants in the environment depends, besides abiotic factors, on host characteristics, such as chemical composition and bark morphology, which are important for the establishment and development of individuals (Benzing 1990). Factors such as tree bark pH and water retention capacity are mainly related to the size and age of the individuals studied, and more specifically, to trunk diameter, bark thickness and depth of cracks in its structure (Fritz et al. 2009). While $\mathrm{pH}$ is a chemical factor that regulates mainly nutrient availability (Nash 2008), bark water retention capacity acts in water supplying

\footnotetext{
${ }^{1}$ Universidade Feevale, Lab. Biotecnologia Vegetal, Prog. Pós-graduação em Qualidade Ambiental, ERS 239, 2755, 93525-075, Novo Hamburgo, RS, Brasil.

${ }^{2}$ Universidade Feevale, Lab. Biotecnologia Vegetal, ERS 239, 2755, 93525-075, Novo Hamburgo, RS, Brasil.

${ }^{3}$ Author for correspondence: deliojendres@hotmail.com
} 
to epiphytic species, along with precipitation, air humidity and evaporation (Hauck et al. 2000).

Thinner layers of dead tissue, which commonly line younger branches and tree trunks, allow some ion mobility between the nearest functional inner tissues and the bark (Legrand et al. 1996). As the bark increases in thickness and age, the ions from the outermost part are leached, changing the quality of the substrate available for the epiphytic flora (Farmer et al. 1991). For many species, as the trunk increases in diameter, successive layers of rhytidoma that remain strongly attached to the bark, crack and expose periderm layers of different thicknesses (Legrand et al. 1996). These variations between regions with different bark thicknesses, either in the cracks formed during growth on the older parts of the tree, or even in younger regions, such as in upper branches, may also vary according to intrinsic characteristics of the tree species (Legrand et al. 1996).

Tree bark $\mathrm{pH}$ evaluation is important for indirect studies of atmospheric pollutant effects, as well as for understanding the synergistic effects of these substances on the epiphytic species establishment (Bates et al. 1990). The $\mathrm{pH}$ values obtained in studies on tree bark characteristics depends, in addition to the environmental conditions in which trees are inserted, on the age and health of the tree, period of storage in the laboratory, sampling technique, analytical procedure and bark structure (Barkman 1958; Sjörgen 1961; Grodzinska 1979).

As the bark is a solid material, the methods for measuring its $\mathrm{pH}$ involve suspending the samples in aqueous solution and so, allowing hydrogen proton dissolution in the solvent (Kricke 2002). Comparisons among studies are difficult, since methods used to determine bark $\mathrm{pH}$ vary widely (Gustafsson \& Eriksson 1995; Kricke 2002; Suchara 2012). In addition, due to the scarcity of studies in tropical countries, little is known about tree bark physical and chemical characteristics and the factors involved in their relationship with the occurrence of vascular epiphytes, such as orchids, which are more diverse and abundant in tropical regions (Gentry \& Dodson 1987; Migenis \& Ackerman 1993).

The reintroduction and monitoring of in vitro propagated epiphytic orchids allows the understanding of the relationships they establish with the biotic and abiotic components of the environment (Falk et al. 1996; Kaye 2009), and provide a theoretical basis to recovery and regeneration of threatened orchid species (Rubluo et al. 1993). However, although there are studies describing the establishment of epiphytic orchids in situ, there is no record of how host tree bark characteristics may influence plant development (Seeni \& Latha 2000; Decruse et al. 2003; Zettler et al. 2007; Aggarwal et al. 2012; Wu et al. 2014).

The objective of the study was to analyze if different methodologies to evaluate the bark $\mathrm{pH}$ could influence the results. We also investigated if $\mathrm{pH}$, water retention capacity and thickness of bark samples collected from the trunk and the crown of arboreal phorophytes could influence the development of Cattleya intermedia Graham (Orchidaceae) plants, which were in situ reintroduced for conservation purposes. Our hypotheses were that (i) solvent volume and suspension time affect $\mathrm{pH}$ values recorded for the C. intermedia host tree bark; (ii) there are differences between bark traits of tree zones and tree species; and (iii) the bark traits influence the development of the reintroduced orchids.

\section{Material and Methods}

Epiphyte species studied and plants produced

Cattleya intermedia is an epiphytic Orchidaceae endemic in Atlantic Forest and is endangered at national level in Brazil and regional level in the state of Rio Grande do Sul (Martinelli \& Moraes 2013; Rio Grande do Sul 2014). In vitro propagation, acclimatization, reintroduction and monitoring of populations were performed in the last decade, which provided the initial information so that the individuals used in this study could be obtained and its initial stages of development (Sasamori et al. 2014, 2015; Endres Júnior et al. 2015).

The reintroduced $C$. intermedia plants were obtained by in vitro sowing (Sasamori et al. 2015) and acclimatized in transparent plastic containers, containing adequate substrate for their survival and development. They were kept under controlled temperature of $26 \pm 1{ }^{\circ} \mathrm{C}$ (Sasamori et al. 2014). Five months after the beginning of acclimatization, the plants were tied to pine bark pieces $(5 \times 10$ $\mathrm{cm})$, and they were also cultivated under the same acclimatization conditions (Endres Júnior et al. 2015). After a period of twelve months, 140 plants attached to the pine bark substrate were selected for reintroduction (Fig. 1a). 
Study site, host selection

and reintroduction

The study was developed in the Relevant Ecological Interest Area Henrique Luís Roessler

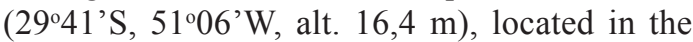
municipality of Novo Hamburgo, in the Sinos River
Basin, state of Rio Grande do Sul, Brazil. The park is inserted in the urban matrix of the city and has an area of 51.4 ha, composed by fields, wetlands and secondary forest belonging to the Semidecidual Lowland Forest, a formation of Atlantic Forest (IBGE 2012).
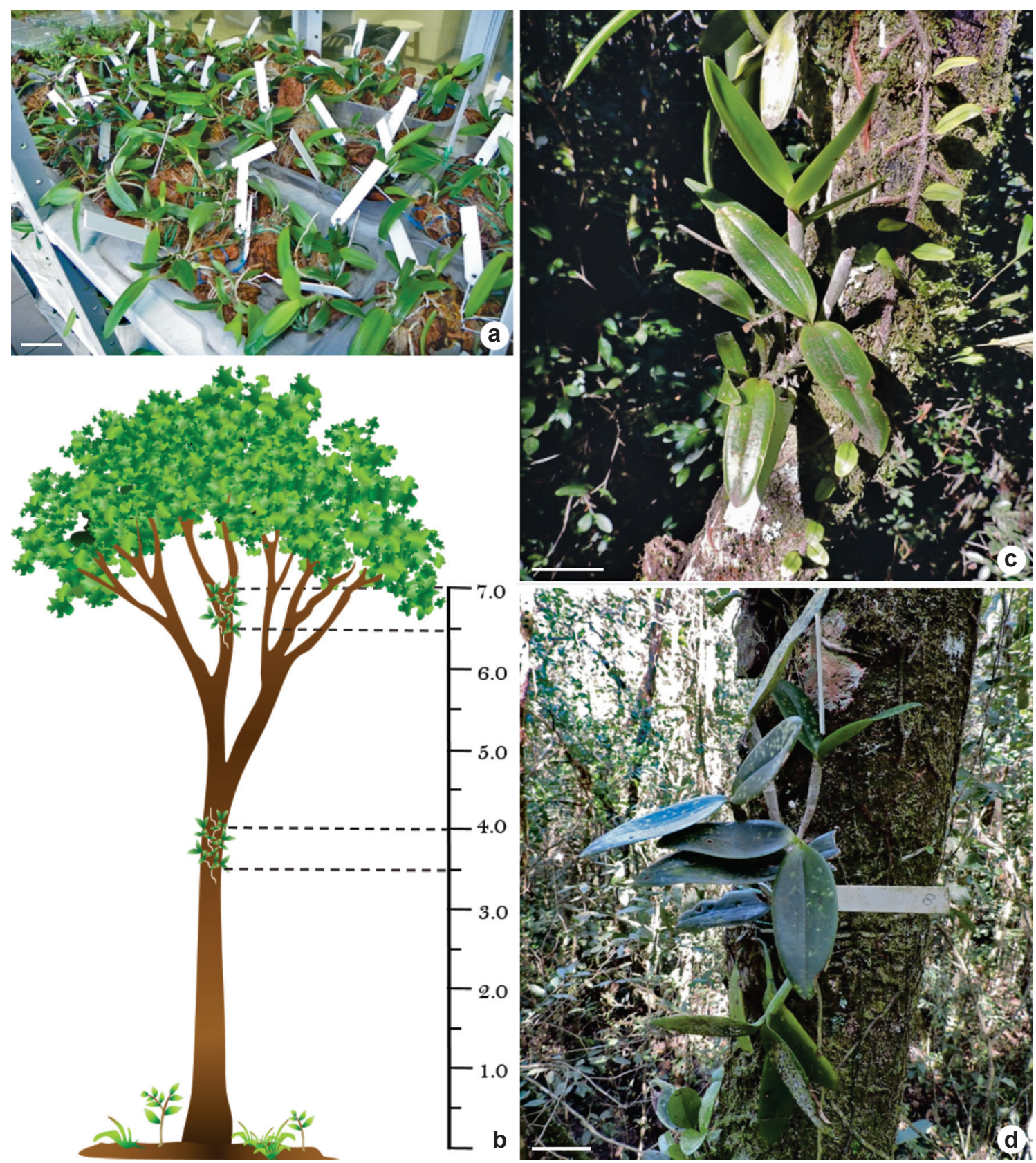

Figure 1 - a. Cattleya intermedia plants attached to pine bark substrate in the laboratory; b. illustrative scheme of a phorophyte indicating the height at which the plants were attached; c. plants growing at the crown; d. plants growing at the trunk of the tree. Scale bar $=4 \mathrm{~cm}$. 
In the forest, the epiphytic flora is mainly composed by Orchidaceae, such as Cattleya intermedia, Gomesa flexuosa (Sims) M.W. Chase \& N.H. Williams, Trichocentrum pumilum (Lindl.) M.W. Chase \& N.H. Williams, Campylocentrum aromaticum Barb.Rodr., by Pleopeltis pleopeltifolia (Raddi) Alston, Microgramma vacciniifolia (Langsd. \& Fisch.) and M. squamulosa (Kaulf.) de la Sota (Polypodiaceae), and by Tillandsia geminiflora Brogn., T. aeranthos (Loisel.) L.B. Sm and Vriesea Lindl. species (Bromeliaceae). Myrtaceae trees predominate among epiphyte hosts, and the natural occurrence of $C$. intermedia and the other epiphyte species indicates that their phorophytes are suitable for the establishment of propagated plants.

Among the natural hosts, we selected trees that presented structural traits that would allow determine two distinct zones: trunk (portion between the base of the tree and the point where the first branches originate) and inner crown (portion between the base of the primary branches and insertion of the secondary branches). Each tree should have a diameter equal to or greater than $10 \mathrm{~cm}$ and a trunk of at least four meters height. So, it was possible to select fourteen phorophytes, identified as Myrcia brasiliensis Kiaersk. (nine individuals), Myrcia glabra (O. Berg) D. Legrand (three individuals), both belonging to Myrtaceae, and Myrsine coriacea (Sw.) R.Br. ex Roem. \& Schult. (two individuals), belonging to Primulaceae. All tree species have a rough persistent bark, even the two Myrtaceae, which elsewhere includes many species with a smooth deciduous bark. The species classification was based on the Angiosperm Phylogeny Group classification system (APG IV 2016) after sample collection of branches with leaves, flowers and fruits. On each phorophyte, ten individuals of $C$. intermedia were attached, five of which were tied to the trunk (between 3.0 and $3.5 \mathrm{~m}$ ) and to the inner crown (between 6.5 and $7.0 \mathrm{~m}$ ), respectively (Fig. 1b).

The plants were reintroduced in the spring of 2013 and the development was evaluated at 720 days after their attachment to the trunk and to the crown (Fig. 1c-d). For that, shoot height of each individual was measured ( $\mathrm{SH}$ - measured in $\mathrm{cm}$ from the base of the rhizome to the tip of the largest leaf) and the number of roots attached to the phorophyte bark was counted (NR - minimum of $2.0 \mathrm{~cm}$ in length).
Sampling of phorophyte barks

Bark samples $(2.5 \times 2.5 \mathrm{~cm})$ of Myrcia brasiliensis, M. glabra and Myrsine coriacea specimens were collected using a sharp chisel (blade width $2.5 \mathrm{~cm}$ ) and a hammer, placed in polyethylene packages and kept in a cold box until delivered to the laboratory, when they were immediately taken for the treatment. As bark thickness is variable according to the tree species and the age of the branch, the samples collected were the ones that encompassed the entire rhytidome surface up to the active phloem.

Methodology test for the determination of the $\mathrm{pH}$ of the host tree barks

For the $\mathrm{pH}$ test in different volumes and suspension times, six samples of each of the nine specimens of M. brasiliensis hosting C. intermedia, collected at breast height, were used. The choice for this species was based on the fact that it is the one with the largest number of individuals among those selected for $C$. intermedia reintroduction. The samples had their mass measured using a precision analytical balance (Ohaus ${ }^{\circledR}$, model PA214CP) and were oven-dried at $80{ }^{\circ} \mathrm{C}$ until they reached a constant mass, which was recorded.

The samples were distributed in a $2 \times 3 \times 9$ factorial experiment, with two volumes of distilled water (10 and $20 \mathrm{~mL}^{-1} \mathrm{~g}$ of dry mass), three suspension times in the solvent solution (1, 4 and $24 \mathrm{~h}$ ), determined according to literature review, and nine repetitions per treatment. Bark samples were individually suspended in $200 \mathrm{~mL}$ vials, which were covered to reduce contamination with atmospheric $\mathrm{CO}_{2}$. The distilled water $\mathrm{pH}$ was initially adjusted to 7.0. At the end of each suspension period, $\mathrm{pH}$ was measured using a $\mathrm{pH}$ meter (Hanna Instruments, model HI2221) with glass electrode. The experiment was performed in the spring of 2015 and repeated in the autumn of 2016 .

Evaluation of host tree bark $\mathrm{pH}$, water retention capacity and thickness determination in different tree zones

To evaluate $\mathrm{pH}$, water retention capacity and bark thickness, four samples of each tree individual were collected from the three tree species, two from the trunk and two from the crown, near the point where the plants of $C$. intermedia were growing. The samples were taken in the autumn of 2016, after the $\mathrm{pH}$ methodology test. 
$\mathrm{pH}$ : drying and mass measurement occurred as described in the previous experiment. The barks were suspended in distilled water (adjusted $\mathrm{pH}$ 7.0) at the rate of $10 \mathrm{~mL}^{-1} \mathrm{~g}$ of dry bark mass, and their $\mathrm{pH}$ was measured after one hour using a glass electrode coupled to the $\mathrm{pH}$ meter under the same $\mathrm{pH}$ test conditions. The determination of this method for $\mathrm{pH}$ measurement takes into account results obtained in the present study (methodology test), in accordance with the procedures adopted by Öztürk \& Oran (2011), which used the same ratio between solvent and bark adopted here.

Water retention capacity: bark samples had their thickness measured using a pachymeter prior to their drying and the total volume of each sample (in $\mathrm{cm}^{3}$ ) was calculated by using the formula $\mathrm{V}=\mathrm{A} \times \mathrm{T}$, in which A corresponds to the area of the sample, and $\mathrm{T}$ to its thickness. The same bark samples used for $\mathrm{pH}$ measurement were suspended for up to $24 \mathrm{~h}$. Afterwards, they were taken from the vials and the excess water was removed with the aid of absorbent paper, and the initial mass (IM) was measured using an analytical balance. The samples were kept in an oven at $80^{\circ} \mathrm{C}$ until they reached a constant mass, called the final mass (FM). The mass of water retained per sample was calculated (IM-FM), and the values were transformed into $\mathrm{mL}$. The volume of water per volume of bark was calculated and the values were expressed in $\mathrm{mL} \mathrm{cm}^{-3}$.

\section{Statistical Analysis}

Data were submitted to the Shapiro-Wilk normality test. The comparisons between the different solvent volumes for the $\mathrm{pH}$ methodology test, and those between trunk and crown were performed by the Mann-Whitney test. The comparisons between bark samples suspension times, as well as parameters comparisons among the tree species were performed using the Kruskal-Wallis test, followed by StudentNewmann-Keuls test.

Shoot height values and number of roots fixed to the phorophyte were compared between the $C$. intermedia plants reintroduced on each phorophyte species using the Kruskal-Wallis test, followed by the Student-Newmann-Keuls. The comparison between parameters of the plants attached to the trunk and to the crown was performed using the Mann-Whitney test. The Spearman's rank correlation test was applied to verify the relationships between phorophytes bark $\mathrm{pH}$ and thickness with the development of the reintroduced C. intermedia individuals. The statistical analyses were conducted using SPSS version 22 (SPSS, Chicago, IL, USA) and BioEstat version 5.3 (Ayres et al. 2007) at 5\% significance

\section{Results}

Methodology test for the determination of host tree bark $\mathrm{pH}$

The $\mathrm{pH}$ of the samples differed significantly when the suspension times were compared. The higher the time, the lower the values obtained in both spring of 2015 and autumn of 2016 samplings in each of the water volumes used in the suspension (Tab. 1). Values of $\mathrm{pH}$ also differed significantly according to the solvent volume used per gram

Table 1 - Comparison of $\mathrm{pH}$ values (average \pm standard deviation) obtained from different suspension times of bark samples in different volumes of distilled water.

\begin{tabular}{lcccccc}
\hline Season & & $\mathbf{1}$ hour & $\mathbf{4}$ hours & $\mathbf{2 4}$ hours & H & p \\
\hline & $10 \mathrm{~mL}$ & $4.73 \pm 0.31 \mathrm{a}$ & $4.41 \pm 0.27 \mathrm{~b}$ & $4.21 \pm 0.26 \mathrm{c}$ & 26.977 & $<0.001$ \\
Spring & $20 \mathrm{~mL}$ & $4.85 \pm 0.36 \mathrm{a}^{*}$ & $4.54 \pm 0.31 \mathrm{~b}^{*}$ & $4.36 \pm 0.30 \mathrm{c}^{*}$ & 27.041 & $<0.001$ \\
2015 & $\mathrm{U}$ & 85 & 78 & 76 & & \\
& $\mathrm{p}$ & 0.015 & 0.008 & 0.007 & & \\
\hline \multirow{2}{*}{ Autumn } & $10 \mathrm{~mL}$ & $4.75 \pm 0.22 \mathrm{a}$ & $4.53 \pm 0.25 \mathrm{~b}$ & $4.28 \pm 0.29 \mathrm{c}$ & 26.694 & $<0.001$ \\
2016 & $20 \mathrm{~mL}$ & $4.91 \pm 0.26 \mathrm{a}^{*}$ & $4.68 \pm 0.27 \mathrm{~b}^{*}$ & $4.40 \pm 0.31 \mathrm{c}^{*}$ & 26.047 & $<0.001$ \\
& $\mathrm{U}$ & 88 & 84 & 93 & & \\
& $\mathrm{p}$ & 0.019 & 0.014 & 0.029 & & \\
\hline
\end{tabular}

Values on the line followed by different letters indicate a significant difference according to Student-Newmann-Keuls test, at $5 \%$ probability. * Indicates significant difference between $\mathrm{pH}$ values in different solvent volumes, according to Mann-Whitney test, at $5 \%$ probability. $\mathrm{H}=\mathrm{H}-\mathrm{value}$ of Kruskal-Wallis test. $\mathrm{U}=\mathrm{U}$-value of Mann-Whitney test. 
of bark, showing that $20 \mathrm{~mL}$ of distilled water for each sample gram was superior when using $10 \mathrm{~mL}$ of solvent. These differences occurred in each of the bark suspension times, in the two samplings analyzed (Tab. 1).

Evaluation of host tree bark $\mathrm{pH}$, water retention capacity and thickness determination in different tree zone

Bark $\mathrm{pH}$ and water retention capacity did not differ significantly between trunk and crown of the three tree species studied. Thus, for each parameter, the values obtained for the two tree zone were pooled to be compared between the tree species (Tab. 2). As the thickness of the bark was higher for the trunk relative to the crown samples of Myrsine coriacea (U $=11.0 ; \mathrm{p}=0.0274$ ), the two tree zone were evaluated separately for the tree species comparison to this parameter (Tab. 2).

The $\mathrm{pH}$ was significantly higher for Myrsine coriacea bark samples in relation to Myrcia brasiliensis and M. glabra barks. Water retention capacity was statistically equal among the three species (Tab. 2). Myrsine coriacea had higher bark thickness in relation to the two species of Myrcia, both for trunk and crown samples.

Table 2 - Bark pH, water retention capacity (WRC) and thickness (average \pm standard deviation) comparison between samples collected from Myrcia brasiliensis, Myrcia glabra and Myrsine coriacea.

\begin{tabular}{lccccc}
\hline Parameter & M. brasiliensis & M. glabra & M. coriacea & H & p \\
\hline $\mathrm{pH}$ & $4.74 \pm 0.27 \mathrm{~b}$ & $4.63 \pm 0.23 \mathrm{~b}$ & $5.19 \pm 0.31 \mathrm{a}$ & 13.8977 & 0.001 \\
WRC $\left(\mathrm{mL} \mathrm{cm}^{-3}\right)$ & $0.57 \pm 0.18 \mathrm{a}$ & $0.49 \pm 0.14 \mathrm{a}$ & $0.50 \pm 0.07 \mathrm{a}$ & 4.1968 & 0.1227 \\
Crown bark thickness $(\mathrm{mm})$ & $0.46 \pm 0.16 \mathrm{~b}$ & $0.36 \pm 0.12 \mathrm{~b}$ & $0.61 \pm 0.13 \mathrm{a}$ & 17.7598 & $<0.001$ \\
Trunk bark thickness $(\mathrm{mm})$ & $0.50 \pm 0.17 \mathrm{~b}$ & $0.41 \pm 0.11 \mathrm{~b}$ & $0.85 \pm 0.21 \mathrm{a}^{*}$ & 9.655 & 0.008 \\
\hline
\end{tabular}

Different letters indicate significant difference between values in each line, comparing tree species, according to Student-Newmann-Keuls test, at $5 \%$ probability.

* Indicates significant difference between thickness values for Myrsine coriacea, according to Mann-Whitney test, at 5\% probability. $\mathrm{H}=\mathrm{H}$-value of Kruskal-Wallis test.

Reintroduced plants development

Shoot height (SH) of the plants did not differ significantly between phorophyte species both for that individuals reintroduced on the trunk $(\mathrm{H}=0.9011 ; \mathrm{p}=0.637)$, and for that attached in the crown $(\mathrm{H}=0.7657 ; \mathrm{p}=0.682)$. Likewise, no significant differences were observed for the number of roots (NR) of the plants attached to the distinct tree species, both on the trunk $(\mathrm{H}=$
$3.2765 ; \mathrm{p}=0.194)$ and in the crown $(\mathrm{H}=0.0426 ; \mathrm{p}$ $=0.979)$. Therefore, for each parameter, an average was calculated on the basis of the data obtained for the three types of phorophytes. The average SH of the plants was significantly higher in the crown in relation to the trunk $(\mathrm{U}=1488.00, \mathrm{p}<0.001)$. The average NR was also higher in the crown in relation to the trunk $(\mathrm{U}=1282.50, \mathrm{p}<0.001)$ (Tab. 3). SH and NR were not related to $\mathrm{pH}$ and bark thickness.

Table 3 - Shoot height (SH in $\mathrm{cm}$ ) and number of roots (NR) (average \pm standard deviation) of Cattleya intermedia reintroduced on the trunk and in the crown of Myrcia brasiliensis, Myrcia glabra, Myrsine coriacea after 720 days in situ.

\begin{tabular}{lccccc}
\hline Parameter & Tree zone & M. brasiliensis & M. glabra & M. coriacea & Average value \\
\hline SH & Crown & $10.4 \pm 2.9$ & $11.3 \pm 3.2$ & $11.6 \pm 2.8$ & $10.9 \pm 2.9^{*}$ \\
& Trunk & $9.0 \pm 2.1$ & $9.4 \pm 1.4$ & $8.8 \pm 3.6$ & $9.0 \pm 2.3$ \\
NR & Crown & $6.0 \pm 2.6$ & $5.7 \pm 3.5$ & $7.6 \pm 3.0$ & $6.1 \pm 2.8^{*}$ \\
& Trunk & $4.0 \pm 2.5$ & $3.8 \pm 1.5$ & $3.9 \pm 2.0$ & $4.0 \pm 2.3$ \\
\hline
\end{tabular}

* Indicates significant difference according to the Mann-Whitney test, at 5\% probability, comparing tree zones for each parameter, in the last column. 


\section{Discussion}

The present study demonstrated that factors such as solvent volume and suspension time of the bark influence the final $\mathrm{pH}$ values obtained. The distilled water used in the experiments had initial $\mathrm{pH}$ adjusted at 7.0, as mentioned by other studies (Everhart et al. 2008, 2009), and less the time the bark was maintained in solution, higher the $\mathrm{pH}$ values were. The solution acidifies over time, possibly due to continuous cation exchange between the bark and the solvent. The larger periods used in the bark samples suspensions verified in the literature consulted were 48 hours (Grodzinska 1979; Suchara 2012). However, longer immersion times may have other influences besides bark characteristics and the time required for $\mathrm{pH}$ values to stabilize. Among them, we can mention $\mathrm{CO}_{2}$ contamination (Schmidt et al. 2001; Fritz et al. 2009), as well as the bark decomposition process itself, which can acidify the samples (Oliveira et al. 2009). We observed this process by bark fragmentation and due to the characteristic smell of organic matter in decomposition.

The commonly used solvents are deionized water, distilled water and potassium chloride $(\mathrm{KCl})$ in different concentrations. In addition, the solvent volume is quite variable. Small volumes, such as 0.5 $\mathrm{mL}$ of $\mathrm{KCl}$, may be used, in which samples can stay for relatively short times, from one minute (Marmor et al. 2010) to one hour (Kermit \& Gauslaa 2001), due to the highest efficiency of this solution in cation exchange between bark and solvent (Farmer et al. 1990). In addition, low solvent amount does not support the use of conventional electrodes that depend on immersion. As an alternative, flathead electrodes can be used and their higher cost is their main disadvantage (Kricke 2002). Thus, there are studies that use larger solvent volumes, which may be 10 (Fritz \& Heilmann-Clausen 2010), 16 (Suchara 2012) or $20 \mathrm{~mL}$ (Öztürk \& Oran 2011) of deionized or distilled water, or even higher, such as those developed by Everhart et al. (2008, 2009), which suspended bark samples in $35 \mathrm{~mL}$ of deionized water for 24 hours. However, most studies do not standardize the liquid volume in relation to the bark volume.

The solvent volume in relation to the sample volume showed influence on the results, since the $\mathrm{pH}$ values were significantly higher in the treatment where $20 \mathrm{~mL}$ of water were used for the suspension of each gram of sample. In larger water volumes, hydrogen ion concentration released by the bark sample was proportionally lower, reflecting a $\mathrm{pH}$ closer to the initial $\mathrm{pH}$ of the distilled water, which was adjusted to 7.0. Some authors describe sample collection considering its area or diameter (Gustafsson \& Eriksson 1995; Legrand et al. 1996; Kermit \& Gauslaa 2001). Sometimes, they refer to sample thickness in millimeters (Grodzinska 1979; Kermit \& Gauslaa 2001), in order to collect only the bark outermost layer, which would be in direct association with the epiphytic flora (Gustafsson \& Eriksson 1995; Kricke 2002). In the present study, the collection was not limited to a thin outer layer, respecting the presence of cracks in the species bark naturally formed by the thickness growth, and the possibility that there are to some extent ion changes, between the innermost layers and the surface of the bark (Legrand et al. 1996). Thus, bark dead tissue was collected, regardless of its thickness, with samples of determined areas. The weighing of the dried barks allowed proportional amounts of solvent to be used for each sample, which was essential to the determination of the results. In the literature, the solvent amounts used for each gram of sample are sometimes mentioned, although each study applies a different volume, restricting comparisons (Fritz \& Heilmann-Clausen 2010; Öztürk \& Oran 2011).

Values of $\mathrm{pH}$ tend to be lower in upper tree regions due to deposition and action of substances present in the atmosphere that may react with the bark, acting on cation leaching through the trunk (Richardson 1988; Bates et al. 1990). In addition, in the tree upper regions, dead tissue layer thickness is commonly lower relative to the lower regions (Everhart et al. 2009), which may allow some ion mobility between the nearest functional inner tissues and bark (Legrand et al. 1996). In the present study, equal bark thickness between the tree zone observed in M. brasiliensis and M. glabra, as well as other possible differences in the intrinsic characteristics of the studied species, such as bark structure and organic and inorganic substances impregnation, may have influenced $\mathrm{pH}$ values. Here, a smaller stature of the studied trees was verified in relation to other studies, where a trunk-crown gradient was distinguished for the physical and chemical and structural characteristics (Everhart et al. 2009; Marmor et al. 2010). The arboreal individuals evaluated presented height between eight and ten meters, allowing a smaller spatial difference between the determined bark collection points at the trunk and at the crown, which was three meters.

Myrsine coriacea presented higher bark thickness at the trunk in relation to the crown, while 
water retention capacity the average was equal for the three species. It is described in the literature that the tree bark presents a higher thickness in the lower zones of the trees (Everhart et al. 2009), which tends to be formed by older plant tissues and with a greater water retention capacity (Callaway et al. 2001, 2002; Zotz \& Vollrath 2003; Hietz 2005). However, since there was no significant difference in the present study, we can inferred that this characteristic depends not only on the tree branches age, but also on the physical and chemical characteristics that compose the studied tissues, and that can also vary according to the tree species (Fritz et al. 2009). Myrsine coriacea bark samples had higher $\mathrm{pH}$ in relation to the other tree species of this study. Angiosperms bark $\mathrm{pH}$ tends to be more basic than that of gymnosperms, although important variations may also occur among species of this group (Grodzinska 1979; Schmidt et al. 2001; Everhart et al. 2009).

The development of $C$. intermedia plants was not related to $\mathrm{pH}$, water retention capacity and bark thickness. Relationships between tree bark characteristics and epiphytic species distribution are recorded for other groups of organisms and these studies concentrate in North America, Europe and Asia (Everhart et al. 2008, 2009; Bates et al. 1990; Gustafsson \& Eriksson 1995; Kermit \& Gauslaa 2001; Marmor et al. 2010; Öztürk \& Oran 2011; Suchara 2012; Fritz \& Heilmann-Clausen 2010). Little is known about such relationships involving vascular epiphytic plants (Wagner et al.2015). Becker et al. (2015) observed that the bark $\mathrm{pH}$ does not show an adequate predictor for epiphytic flora distribution in southern Brazil. However, the results obtained can be related with some of the methodological characteristics applied. The reintroduced plants were initially established on a pinus bark base, which may have reduced the possible influence of bark characteristics on individual's development, even though all of them fixed their roots directly on trees. Also, the plants have already an average height of $8.4 \mathrm{~cm}$ and one or more pseudobulbs formed when reintroduced. This may have reduced external factors influences, such as those related to tree barks on their establishment. According to Zotz \& Schmidt (2006), orchid germination and early development are the most vulnerable stages, so that, as these steps were performed in the laboratory under controlled conditions, they may have increased the successful establishment of the reintroduced individuals.

As many epiphyte species exhibit homeohydric habits, requiring a minimum hydration level in their primary tissues to survive (Evenari 1985), individuals present a series of morphological and physiological adaptations that allow their development under water-restricted conditions (Benzing 1990). Multiple stem organs formation, verified mainly in sympodial growth orchids, as well as the presence of velamen on the roots and some degree of foliar succulence, as observed in C. intermedia (Gonçalves \& Waechter 2003), allow that water relations do not depend heavily on the leaves, since an important part of the plant biomass is composed of other organs (Zotz 1999; Zotz \& Hietz 2001). Water can be translocated to the leaves, when necessary, or kept in these reserve organs during periods of drought (Zotz 1999; Zotz \& Hietz 2001). Vascular epiphytes absorb much of their nutrients directly from the atmosphere, either by suspended particles, direct rainwater or leached from the canopies (Kersten 2010). Thus, the dependence of C. intermedia individuals on the characteristics of the substrate they are attached may be lower, since the $\mathrm{pH}$, for instance, is related to the availability and uptake of nutrients by the roots (Nash 2008). Vascular epiphytes have their establishment and development dependent on a number of other environmental factors, such as luminosity, nutrient availability, temperature, relative humidity, as well as other characteristics of the trees on which they are attached, as stem inclination and diameter (Kersten 2010; Gowland et al. 2011). Thus, one or more of these parameters that were not mentioned in the present study may have a greater influence on the establishment of $C$. intermedia reintroduced plants.

\section{Conclusion}

Our results showed that variation in sample suspension time and the solvent volume can influence on the obtained results, and thus, it is important to adopt a standardized methodology that allows data comparison between studies. The bark traits analyzed presented different patterns according the tree zone and species. Since these patterns were distinct from the development behavior of the plants, no relation was observed between them. This indicates that the reintroduced plants establish complex interactions with the biotic and abiotic components of the environment, which reinforces the importance to consider the methods and the growth conditions of the plants to be used in the reintroduction processes. The data contribute with unprecedented information for the application of future vascular epiphyte studies, where new parameters and relations can be explored, ensuring success in the conservation of endangered species. 


\section{Acknowledgements}

We thank the University for providing infrastructure and financial support; the Coordenação de Aperfeiçoamento de Pessoal de Nível Superior (CAPES) for the grants awarded to the first and second authors; and the Fundação de Amparo à Pesquisa do Estado do Rio Grande do Sul (FAPERGS) for the grants awarded to the third and fourth authors.

\section{References}

Aggarwal S, Nirmala C, Beri S, Rastogi S \& Adholeya A (2012) In vitro symbiotic seed germination and molecular characterization of associated endophytic fungi in a commercially important and endangered indian orchid Vanda coerulea Griff. ex Lindl. European Journal of Environmental Sciences 2: 33-42.

APG IV - Angiosperm Phylogeny Group (2016) An update of the Angiosperm Phylogeny Group classification for the orders and families of flowering plants: APG IV. Botanical Journal of the Linnean Society 181: 1-20.

Ayres M, Ayres Jr.M, Ayres DL \& Santos AS (2007) Bioestat 5.3. Available at $<$ https://www.mamiraua.org.br/pt-br/ downloads/programas/bioestat-versao-53/>. Access on 10 January 2016.

Barkman JJ (1958) Phytosociology and Ecology of Cryptogamic Epiphytes. $2^{\text {nd }}$ ed. Van Gorcum, Assen. $628 \mathrm{p}$.

Bates JW, Bell JNB \& Farmer AM (1990) Epiphyte recolonization of oaks along a gradient of air pollution in southeast England. 1979-1990. Environmental Pollution 68: 81-99.

Becker DFP, Müller A \& Schmitt JL (2015) Influência dos forófitos Dicksonia sellowiana e Araucaria angustifolia sobre a comunidade de epífitos vasculares em floresta com araucária. Floresta 45: 781-790.

Benzing DH (1990) Vascular epiphytes: general biology and related biota. Cambridge University Press, Cambridge. 354p.

Callaway RM, Reinhart KO, Tucker SC \& Pennings SC (2001) Effects of epiphytic lichens on host preference of the vascular epiphyte Tillandsia usneoides. Oikos 94: 433-441.

Callaway RM, Reinhart KO, Moore GW, Moore DJ \& Pennings SC (2002) Epiphyte host preferences and host traits: mechanisms for species-specific interactions. Oecologia 132: 221-230.

Decruse SW, Gangaprasad A, Seeni S \& Menon S (2003) Micropropagation and ecorestoration of Vanda spathulata, an exquisite orchid. Plant Cell, Tissue and Organ Culture 72: 199-202.

Endres Júnior D, Sasamori MH, Silveira T, Schmitt JL \& Droste A(2015) Reintrodução de Cattleya intermedia Graham (Orchidaceae) em borda e interior de um fragmento de Floresta Estacional Semidecidual no sul do Brasil. Revista Brasileira de Biociências 13: 33-40.

Evenari M (1985) Adaptations of plants and animals to the desert environment. In: Evenari M, Noy-Meir I \& Goodall DW (eds.) Hot deserts and arid shrublands. Elsevier Science Publishers, Amsterdam. Pp. 79-93.

Everhart SE, Ely JS \& Keller HW (2009) Evaluation of tree canopy epiphytes and bark characteristics associated with the presence of corticolous myxomycetes. Botany 87: 509-517.

Everhart SE, Keller HW \& Ely JS (2008) Influence of bark $\mathrm{pH}$ on the occurrence and distribution of tree canopy myxomycete species. Mycologia 100: 191-204.

Falk DA, Millar CI \& Olwell M (1996) Guidelines for developing a rare plant reintroduction plan. In: Falk DA, Millar CI \& Olwell M (ed.) Restoring diversity: strategies for reintroduction of endangered plants. Island Press, Washington. Pp. 453-490.

Farmer AM, Bates JW \& Bell JNB (1990) A comparison of methods for the measurement of bark $\mathrm{pH}$. Lichenologist 22: 191-197.

Farmer AM, Bates JW \& Bell JNB (1991) Seasonal variations in acidic pollutant inputs and their effects on the chemistry of stemflow, bark and epiphyte tissues in thee oak woodlands in N.W. Britain. New Phytologist 118: 441-451.

Fritz O, Brunet J \& Caldiz M (2009) Interacting effects of tree characteristics on the occurrence of rare epiphytes in a Swedish beech forest area. The Briologist 112: 488-505.

Fritz O \& Heilmann-Clausen J (2010) Rot holes create key microhabitats for epiphytic lichens and bryophytes on beech (Fagus sylvatica). Biological Conservation 143: 1008-1016.

Gentry AH \& Dodson CH (1987) Diversity and biogeography of Neotropical vascular epiphytes. Annals of the Missouri Botanical Garden 74: 205-233.

Gonçalves CN \& Waechter JL (2003) Aspectos florísticos e ecológicos de epífitos vasculares sobre figueiras isoladas no norte da planície costeira do Rio Grande do Sul. Acta Botanica Brasilica 17: 89-100.

Gowland KG, Wood J, Clements MA \& Nicotra AB (2011) Significant phorophyte (substrate) bias is not explained by fitness benefits in three epiphytic orchid species. American Journal of Botany 98: 197-206.

Grodzińska K (1979) Tree bark - sensitive biotest for environment acidification. Environment International 2: 173-176.

Gustafsson L \& Eriksson I (1995) Factors of importance for the epiphytic vegetation of aspen Populus tremula with special emphasis on bark chemistry and soil chemistry. Journal of Applied Ecology 32: 412-424.

Hauck M, Jung R \& Runge M (2000) Does waterholding capacity of bark have an influence of lichen performance in dieback-affected spruce forest? Lichenologist 32: 407-409.

Hietz P (2005) Conservation of vascular epiphyte diversity in Mexican coffee plantations. Conservation Biology 19: 391-399.

IBGE - Instituto Brasileiro de Geografia e Estatística (2012) Manual técnico da vegetação brasileira: sistema 
fitogeográfico, inventário das formações florestais e campestres, técnicas e manejo de coleções botânicas, procedimentos para mapeamentos. $2^{\mathrm{a}}$ ed. IBGE, Rio de Janeiro, $275 \mathrm{p}$.

Kaye TN (2009) Toward successful reintroductions: the combined importance of species traits, site quality, and restoration technique. Proceedings of the CNPS Conservation Conference, Sacramento Pp. 99-106.

Kermit T \& Gauslaa Y (2001) The vertical gradient of bark $\mathrm{pH}$ of twigs and macrolichens in a Picea abies canopy not affected by acid rain. Lichenologist 33: 353-359.

Kersten RA (2010) Epífitas vasculares - histórico, participação taxonômica e aspectos relevantes, com ênfase na Mata Atlântica. Hoehnea 37: 9-38.

Kricke R (2002) Measuring bark pH. In: Nimis PL, Scheidegger C \& Wolseley PA (eds.) Monitoring with lichens - monitoring lichens. Kluwer Academic Publishers, Dordrecht. Pp. 333-336.

Legrand I, Asta J \& Goudard Y (1996) Variations in bark acidity and conductivity over the trunk length of silver fir and Norway spruce. Trees 11: 54-58.

Marmor L, Tõrra T \& Randlane T (2010) The vertical gradient of bark $\mathrm{pH}$ and epiphytic macrolichen biota in relation to alkaline air pollution. Ecological Indicators 10: 1137-1143.

Martinelli G \& Moraes MA(2013) Livro vermelho da flora do Brasil. Instituto de Pesquisas Jardim Botânico do Rio de Janeiro, Rio de Janeiro. 1100p.

Migenis LE \& Ackerman JD (1993) Orchid-phorophyte relationships in a forest watershed in Puerto Rico. Journal of Tropical Ecology 9: 231-240.

Nash TH (2008) Nutrients, elemental accumulation, and mineral cycling. In: Nash TH (ed.) Lichen Biology. $2^{\text {nd }}$ ed. Cambridge University Press, Cambridge. Pp. 234-251.

Oliveira TMBF, Souza L \& Castro SSL (2009) Dinâmica da série nitrogenada nas águas da bacia hidrográfica Apodi/Mossoró - RN - Brasil. Eclética Química 34: 17-26.

Öztürk S \& Oran S (2011) Investigations on the bark pH and epiphytic lichen diversity of Quercus taxa found in Marmara region. Journal of Applied Biological Sciences 5: 27-33.

Richardson DHS (1988) Understanding the pollution sensitivity of lichens. Botanical Journal of the Linnean Society 96: 31-43.

Rio Grande do Sul (2014) Decreto $n^{\circ} 52.109$, de 01 de dezembro de 2014. Declara as espécies da flora nativa ameaçadas de extinção no estado do Rio Grande do Sul. Lex-Diário Oficial do Rio Grande do Sul, ano LXXII, n² 233, Pp. 2-11.

Rubluo A, Chávez V, Martínez AP \& Martínez-Vázquez (1993) Strategies for the recovery of endangered orchids and cacti through in vitro culture. Biological Conservation 63: 163-169.

Sasamori MH, Endres Júnior D \& Droste A (2014) Sobrevivência e desenvolvimento de plântulas de Cattleya intermedia Graham (Orchidaceae) micropropagadas e aclimatadas em substrato com fibra de coco. Revista Pesquisas, Botânica 65: 293-303.

Sasamori MH, Endres Júnior D \& Droste A (2015) Asymbiotic culture of Cattleya intermedia Graham (Orchidaceae): the influence of macronutrient salts and sucrose concentrations on survival and development of plantlets. Acta Botanica Brasilica 29: 292-298.

Schmidt J, Kricke R \& Feige GB (2001) Measurements of bark $\mathrm{pH}$ with a modified flathead electrode. The Lichenologist 33: 456-460.

Seeni S \& Latha PG (2000) In vitro multiplication and ecorehabilitation of the endangered Blue Vanda. Plant Cell, Tissue and Organ Culture 61: 1-8.

Sjörgen E (1961) Epiphytische Moosvegetation in Laubwäldern der Insel Oland (Schweden). Acta Phytogeographica Suecica 44: 1-149.

Suchara I (2012) Temporal and spatial changes in spruce bark acidity at the scale of the Czech Republic in the last two decades, and the current abundance of epiphytic lichen Hipogymnia physodes. Water, Air \& Soil Pollution 223: 1685-1697.

Wagner K, Mendieta-Leiva G \& Zotz G (2015) Host specificity in vascular epiphytes: a review of methodology, empirical evidence and potential mechanisms. AOB Plants 7: 1-25.

Wu K, Zeng S, Lin D, Teixeira da Silva JA, Bu Z, Zhang J \& Duan J (2014) In vitro propagation and reintroduction of the endangered Renanthera imschootiana Rolfe. PLOS ONE 9: 1-13.

Zettler LW, Poulter SB, McDonald KI \& Stewart SL (2007) Conservation-driven propagation of an epiphytic orchid (Epidendrum nocturnum) with a mycorrhizal fungus. HortScience 42: 135-139.

Zotz G (1999) What are backshoots good for? Seasonal changes in mineral, carbohydrate and water content of different organs of the epiphytic orchid, Dimerandra emarginata. Annals of Botany 84: 791-798.

Zotz G \& Hietz P (2001) The physiological ecology of vascular epiphytes: current knowledge, open questions. Journal of Experimental Botany 52: 2067-2078.

Zotz G \& Vollrath B (2003) The epiphyte vegetation of the palm Socratea exorrhiza - correlations with tree size, tree age, and bryophyte cover. Journal of Tropical Ecology 19: 81-90.

Zotz G \& Schmidt G (2006) Population decline in the epiphytic orchid Aspasia principissa. Biological Conservation 129: 82-90. 